\title{
Venereal diseases in the islands of the North Pacific
}

\author{
R R WILLCOX \\ From St Mary's Hospital, London
}

SUMMARY Apart from the Japanese islands, and those of Karabati (lately Gilbert Islands), which lie just north of the equator, the islands of the northern Pacific Ocean are either American owned or otherwise administered. Even the Japanese islands were controlled by the USA for varying numbers of years after the second world war. Venereal disease statistics from Guam, the Trust Territory of the Pacific Islands, and the Gilbert Islands have been collated by the South Pacific Commission and will be presented in a second paper. Those from the Hawaiian Islands (the fiftieth state of the USA) are published by the United States Public Health Service and include those from Honolulu, the capital.

While the rates per 100000 for both syphilis and gonorrhoea are lower than those for the USA as a whole, the trends since 1970 have been less satisfactory in the state of Hawaii than for the whole of the United States. While the disturbing increasing incidence of primary and secondary syphilis was checked in 1977, that of gonorrhoea has continued to rise. The number of cases of gonorrhoea also increased in Guam and the Trust Territory of the Pacific Islands but there has been a recent fall from earlier peak figures. The pattern of venereal disease in the most developed Pacific islands is thus gradually approaching what may be expected elsewhere in modern western society and it would seem logical to expect that this trend will continue.

\section{Introduction}

\section{HISTORICAL ASPECTS}

The Pacific Islands have had a mixed and varied past, being discovered, conquered, or otherwise acquired and later administered directly or indirectly under the mandate or trusteeship of the League of Nations after the first world war or of the United Nations after the second world war, by one or more of a number of countries including Australia, Britain, Chile, Ecuador, France, Germany, Holland, Japan, New Zealand, Portugal, Spain, and the USA. In recent years increasing numbers are achieving independence, particularly those south of the equator.

The changing past can well be illustrated by the administration of the Mariana Islands. After occupation by Spain they were sold to Germany in 1899 , placed under Japanese mandate by the Treaty of Versailles in 1919, and after the second world war

*Paper presented at a meeting of the Medical Society for the Study of Venereal Diseases, Lubeck, West Germany, May 1979

Address for reprints: Dr R R Willcox, Tideway, Lonsdale Road, London SW 13

Received for publication 21 August 1979 became part of the Pacific Islands Trust Territory of the USA with the ultimate goal of US commonwealth status.

POLITICAL ASPECTS

The present political attachments of the Pacific islands north of the equator are shown in table $I$.

Thus the relatively few Pacific islands north of the equator are orientated towards the USA. Even the Japanese islands (table I) were controlled by the USA after the second world war, since when their administration has gradually been restored to Japan.

\section{DEMOGRAPHIC ASPECTS \\ Hawaiian group}

The Hawaiian islands are a mixture of high islands, mountainous and volcanic in origin (in some cases volcanoes are still active) with an external coral-reefbounded lagoon, or low coral atolls with an internal lagoon. The centre of the North Pacific Ocean is occupied by the long chain of mixed islands of the Hawaiian group (population 838000 , with the modern sophisticated capital, Honolulu, on the island of Oahu), which became the fiftieth state of the USA in 1959. Midway Island lies near its western extremity. 
TABLE I Political attachments of Pacific Islands north of the equator

\begin{tabular}{|c|c|}
\hline Political attachment & Pacific Islands \\
\hline Independent & $\begin{array}{l}\text { Part of Karabati, lately the } \\
\text { Gilbert Islands (British), including Tarawa } \\
\text { and certain Line Islands (Washington, } \\
\text { Fanning, and Christmas Islands) }\end{array}$ \\
\hline Japan & $\begin{array}{l}\text { Rukyu Islands (including Okinawa) } \\
\text { Bonin and Volcano Islands (including } \\
\text { Iwo Jima) } \\
\text { Ganges Island } \\
\text { Marcus Island }\end{array}$ \\
\hline USA & $\begin{array}{l}\text { Hawaiian Islands } \\
\text { Midway Island } \\
\text { Certain Line Islands (Palmyra, Kingman, } \\
\text { Jarvis) } \\
\text { Johnston } \\
\text { Wake } \\
\text { Guam } \\
\text { US Trust Territory of Pacific Islands } \\
\text { (Marshalls, Carolines and remaining } \\
\text { Marianas) }\end{array}$ \\
\hline
\end{tabular}

\section{Japanese islands}

On the Asian side a chain of volcanic islands, the Ryukyu archipelago, extends south-eastwards towards Taiwan. These comprise 848 square miles of land and are relatively heavily populated (977 000 inhabitants in 1977).

\section{Guam}

Due south of Japan are the 15 Bonin Islands, with $\mathbf{4 0}$ square miles and a population of only 203 in 1965 , and the three Volcano Islands, which are also Japanese. These groups are geographically part of a north-south archipelago, which extends further to include the Marianas; Guam, the 209 square miles of which were seceded to the USA by Spain in 1898 and which had a population in 1979 of 90000 , is the southernmost member.

\section{Trust Territory of Pacific Islands}

The remaining Marianas and the more southerly Caroline and Marshall groups of islands form the US Trust Territory of the Pacific Islands, with a population of 133000 on 707 square miles of land. The 1350 coral islets of the Caroline Islands and the 34 coral atolls of the Marshall Islands stretch from west to east for 4000 miles between $0^{\circ}$ and $10^{\circ}$ north of the equator, leaving only Johnston Island to bridge the long gap of ocean north-east to Hawaii.

\section{Gilbert Islands}

Further south straddling the equator for a similar distance are some members of the Gilbert Islands (266 square miles, population 56000 ). These include the capital, Tarawa (recently the scene of a cholera epidemic), and some of the Line Islands (for example, Christmas Island, the site of nuclear tests between 1957 and 1964). Others lie south of the equator, including Ocean Island (Banaba) and all of the Phoenix Islands.

Described in the popular press as " 33 coral atolls scattered across two million square miles of Pacific" the Gilbert Islands achieved independence on 11 July 1979 and were renamed Karabati.

\section{COMMUNICATIONS}

Sixteen airlines serving the Pacific Islands north of the equator are listed in table II; all but three routes pass through Honolulu. Other internal American airlines connect Honolulu with the mainland of the USA.

East-west communications lie through Guam and Honolulu with a linking island-hopping operation by way of Johnston Island through the Trust Territory of the Pacific Islands (with stops at Majuro and Kwajalein in the Marshall Islands, Ponape and Truk in the Carolines). North-south communications are mainly through Honolulu or Nauru, which lies only a few (26 miles) south of the equator (figure).

TABLE II Airlines* serving the Pacific Islands north of the equator

\begin{tabular}{ll}
\hline External & Internal \\
\hline Air New Zealand (CTE) & Air Nauru (ON)† \\
Canadian Pacific Air (CP) & Air Pacific (FJ)† \\
China Airlines (CI) & Continental Air Micronesia (CO) \\
Japan Airlines (JL) & Hawaiian Airlines (HA) \\
Korean Airlines (KE) & Island Air (IL)*t \\
North-West Orient & \\
Airlines (NW) & \\
Philippine Airlines (PR) & \\
Pan American World & \\
Airways (PA) & \\
Qantas Airways (QF) & \\
Singapore Airlines (SQ) & \\
Western Airlines (WA) &
\end{tabular}

*All but those marked + use Honolulu; letters in parentheses are codes 11

\section{CONSEQUENCES OF WESTERNISATION}

The early voyagers brought many infectious diseases for example, (influenza, measles, pertussis, and some sexually transmitted conditions)-often with drastic consequences-to add to the usual parasitic and other communicable conditions endemic in the then undeveloped tropical areas.

A further marked change has taken place following the more recent vastly increased expansion of air travel and its accompanying tourism and other economic developments. For decades this development has been most advanced in the Hawaiian Islands; Honolulu, with its many modern buildings, may be equated with Miami. However, large hotels are now also appearing elsewhere (there is a Guam 


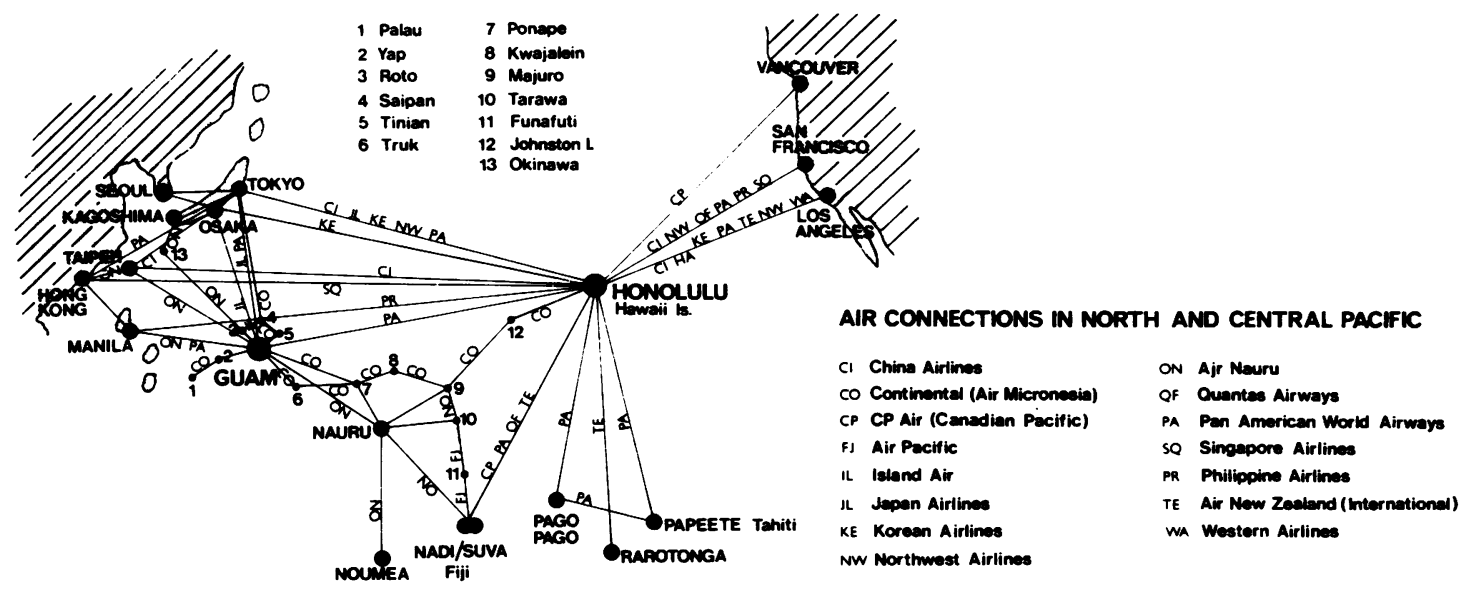

FIG Air connections in North and Central Pacific.

Hilton and a Continental Hotel in Guam and the Palau (Caroline) Islands).

These changes have produced a life style, which, for many of the local inhabitants of the Pacific Islands, has proved far from beneficial. Although a number of communicable diseases are now well controlled (for example, yaws) there has been a recent upsurge of venereal infections and degenerative diseases, such as diabetes, hypertension, and obesity.

For example, in the once phosphate-rich eight square miles of Nauru, which was successively governed by Germany, Britain, and Australia before becoming independent in 1968, there is an annual income of US\$30 000 per head, but $31 \%$ of its 7300 population now have diabetes. ${ }^{12}$

\section{Venereal diseases statistics}

\section{AVAILABLE DATA}

No data are readily available for the Japanese islands. Those for Hawaii and Honolulu are published regularly by the United States Public Health Service together with those for other American states. Figures for the other territories are collated and published by the World Health Organisation and by the South Pacific Commission and are subject to the usual variables-for example, the reliability of diagnosis, intensity of medical services, degree of support by pathology services, extent of reporting, and indeed the vagaries inherent in statistical assembly itself.

\section{DATA FROM HAWAII}

\section{Gonorrhoea}

In the state of Hawaii the rates per 100000 for gonorrhoea have consistently increased from $177 \cdot 4$ in $1970^{3}$ to $398 \cdot 2$ in $1977^{4}$ (table III). Both these figures were lower than those for the United States as a whole, which were $287 \cdot 1$ per 100000 in 1970 and 465.9 per 100000 in 1977 (the figures for 1977 were for the calendar not the fiscal year as previously). Nevertheless the rate for Hawaii had more than doubled during this time compared with only a 1.6-fold increase for the whole of the USA.

The male-to-female ratio for gonorrhoea has increased from $1.04: 1$ in 1975 to $1.38: 1$ in 1977 (table IV). The national average for the United States in 1977 was $1 \cdot 48: 1 .^{4}$

TABLE III Venereal disease in Hawaii ${ }^{3-5}$

\begin{tabular}{|c|c|c|c|c|c|c|c|c|c|c|}
\hline \multirow[b]{3}{*}{ Venereal diseases } & \multicolumn{10}{|c|}{ Fiscal years } \\
\hline & \multicolumn{2}{|l|}{1970} & \multicolumn{2}{|l|}{1972} & \multicolumn{2}{|l|}{1974} & \multicolumn{2}{|l|}{1976} & \multicolumn{2}{|l|}{1977} \\
\hline & $\mathrm{No}^{*}$ & Rate* & No & Rate & No & Rate & No & Rate & No & Rate \\
\hline $\begin{array}{l}\text { Syphilis (total) } \\
\text { Syphilis }\end{array}$ & 66 & $9 \cdot 0$ & 78 & $10 \cdot 6$ & 69 & $8 \cdot 9$ & 133 & $16 \cdot 5$ & 72 & $8 \cdot 6$ \\
\hline $\begin{array}{l}\text { Primary and secondary } \\
\text { Gonorrhoea } \\
\text { Other }\end{array}$ & $\begin{array}{r}8 \\
1265 \\
1\end{array}$ & $\begin{array}{r}1 \cdot 1 \\
177 \cdot 4 \\
0 \cdot 1\end{array}$ & $\begin{array}{r}22 \\
1612 \\
0\end{array}$ & $\begin{array}{c}3 \cdot 0 \\
218 \cdot 4 \\
0\end{array}$ & $\begin{array}{r}38 \\
2182 \\
1\end{array}$ & $\begin{array}{r}4 \cdot 9 \\
281 \cdot 2 \\
0 \cdot 1\end{array}$ & $\begin{array}{r}73 \\
2508 \\
0\end{array}$ & $\begin{array}{c}9 \cdot 1 \\
311 \cdot 2 \\
0\end{array}$ & $\begin{array}{r}36 \\
3337 \\
0\end{array}$ & $\begin{array}{r}4 \cdot 3 \\
398 \cdot 2 \\
0\end{array}$ \\
\hline
\end{tabular}

*Cases and Rates per 100000 population 
TABLE IV Male-to-female ratio for venereal diseases in Hawaii

\begin{tabular}{|c|c|c|c|c|c|c|c|c|c|}
\hline \multirow{2}{*}{$\begin{array}{l}\text { Venereal } \\
\text { disease }\end{array}$} & \multicolumn{3}{|c|}{$1975^{*}$} & \multicolumn{3}{|l|}{$1976^{*}$} & \multicolumn{3}{|c|}{$1977+$} \\
\hline & $M$ & $F$ & Ratio & $M$ & $F$ & Ratio & $M$ & $F$ & Ratio \\
\hline $\begin{array}{l}\text { Syphilis } \\
\text { Primary and }\end{array}$ & & & & & & & & & \\
\hline $\begin{array}{r}\text { secondary } \\
\text { Gonorrhoea }\end{array}$ & $\begin{array}{r}37 \\
1194\end{array}$ & $\begin{array}{r}3 \\
1148\end{array}$ & $\begin{array}{c}12 \cdot 3 \\
1 \cdot 04\end{array}$ & $\begin{array}{r}69 \\
1333\end{array}$ & $\begin{array}{r}4 \\
1176\end{array}$ & $\begin{array}{l}17 \cdot 3 \\
1 \cdot 13\end{array}$ & $\begin{array}{r}29 \\
1936\end{array}$ & $1401^{7}$ & $\begin{array}{l}4 \cdot 1 \\
1 \cdot 38\end{array}$ \\
\hline
\end{tabular}

*Fiscal year 5

+Calendar year ${ }^{4}$

The proportion of gonorrhoea treated in the capital, Honolulu, in 1977, the approximate population of 368000 which represented $44 \%$ of that of Hawaii as a whole, was much higher at $70 \%$, a phenomenon of concentration of venereal disease in the more urban areas which has been apparent for a long time in other large cities of the USA and elsewhere.

\section{Syphilis}

Cases and rates: The total rate for syphilis increased from 9.0 per 100000 in the fiscal year, 1970 , to 16.5 per 100000 in 1976 but fell to $8 \cdot 6$ per 100000 in the calendar year, 1977 (table III). For the USA as a whole the comparable figures were much higher at 44.0 per 100000 in $1970,36 \cdot 3$ in 1976 , and 30.0 in $1970 .^{5}$

The notably increasing rates for total syphilis in Hawaii were due to an increasing number of cases of primary and secondary syphilis, which increased from eight $(12 \cdot 1 \%)$ cases in 1970 to $73(54 \cdot 9 \%)$ cases in 1976 with a slight fall to $36(50 \%)$ cases in 1977 . In the United States as a whole, the percentage of early cases compared with all cases of syphilis rose from $23.0 \%$ in 1970 to $32.5 \%$ in 1976 and $33.1 \%$ in 1977.45

For primary and secondary syphilis (table III) the rates for Hawaii increased from $1 \cdot 1$ per 100000 in 1970 , when the rate was $10 \cdot 1$ per 100000 in the USA, to $9 \cdot 1$ per 100000 in 1976 , when the rate had been reduced to 9.5 per 100000 in the USA as a whole. ${ }^{5}$ Thus, for both syphilis and gonorrhoea the trends have been less satisfactory in Hawaii than the average for the United States as a whole.

Male-to-female ratio: On the basis of relatively few cases the male-to-female ratio in Hawaii has been appreciably higher for primary and secondary syphilis than for gonorrhoea (table IV). During the years when the rates for primary and secondary syphilis were rising sharply the ratio was high, reaching $17 \cdot 3: 1$ in 1976 , but fell with the reduction of cases in 1977. Various factors-such as more intensive contact-tracing for syphilis and more homosexual infections-could explain the difference.

Proportion treated in Honolulu: The proportion of cases of primary and secondary syphilis treated in Honolulu decreased between 1973 and 1977. This trend was not so striking, however, for cases of gonorrhoea (table V). The difference could again be attributable to differing degrees of emphasis on contact-tracing for the two diseases.

TABLE V Proportion of cases of syphilis and gonorrhoea treated in Honolulu compared with Hawaii as a whole

\begin{tabular}{|c|c|c|c|c|c|c|}
\hline \multirow[b]{2}{*}{ No of cases } & \multicolumn{2}{|c|}{$1973^{*}$} & \multicolumn{2}{|c|}{$1976^{*}$} & \multicolumn{2}{|c|}{$1977+$} \\
\hline & No & $\%$ & No & $\%$ & No & $\%$ \\
\hline \multicolumn{7}{|l|}{$\begin{array}{l}\text { Syphilis (primary } \\
\text { and secondary) }\end{array}$} \\
\hline $\begin{array}{l}\text { Honolulu } \\
\text { Helli }\end{array}$ & $\begin{array}{l}48 \\
42\end{array}$ & $87 \cdot 5$ & 56 & $76 \cdot 7$ & $\begin{array}{l}30 \\
19\end{array}$ & $52 \cdot 8$ \\
\hline \multicolumn{7}{|l|}{ Gonorrhoea } \\
\hline Hawaii (total) & 1756 & & 2508 & & 3337 & \\
\hline Honolulu & 1239 & $70 \cdot 6$ & 1692 & $67 \cdot 5$ & 2335 & $70 \cdot 0$ \\
\hline
\end{tabular}

*Fiscal year

†Calendar year

\section{OTHER SEXUALLY TRANSMITTED DISEASES}

Chancroid, lymphogranuloma venereum, and granuloma inguinale, which are classified as "other VD" in USA statistics, are virtually non-existent in Hawaii (table III). Nongonococcal urethritis, which is not reportable on the other hand, is extremely common. Kuberski et al $^{6}$ noted that $75 \%$ of cases of urethritis seen in the Hawaii State Venereal Diseases Clinic in Honolulu were nongonococcal in origin; indeed nearly $70 \%$ of all male patients attending the clinic had this condition. Seventy-three per cent of a selected group of patients had antibodies to herpes virus hominis, $66 \%$ to chlamydia, and $72 \%$ to cytomegalovirus. Moreover, Trichomonas vaginalis was isolated from $24 \%$ of female patients. ${ }^{7}$

\section{GUAM AND THE PACIFIC ISLANDS}

The World Health Organisation ${ }^{8}$ (Causse, G, unpublished data), in its figures for Oceania, provides data on Guam and the Trust Territory of the Pacific Islands. No data are forthcoming for syphilis for either of these territories, but the number of cases of gonococcal infection are shown in table VI. ${ }^{10}$ The number of cases increased in both 
TABLE VI Number of cases of gonococcal infection in Guam and the Trust Territory of the Pacific Islands 9

\begin{tabular}{lll}
\hline Year & Guam & TTPI \\
\hline 1955 & & 599 \\
1966 & & 703 \\
1967 & 236 & 488 \\
1968 & 279 & 497 \\
1969 & & 400 \\
1970 & 231 & 423 \\
1971 & 191 & 661 \\
1972 & 459 & 858 \\
1973 & 422 & 858 \\
1974 & 344 & 629 \\
1975 & 426 & 532 \\
1976 & 354 & 413 \\
\hline
\end{tabular}

TTPI $=$ Trust Territory of the Pacific Islands

territories in the early 1970 s but more recently the number fell from the peak figures obtained.

Figures for these territories, and also for the Gilbert Islands, are collated in the annual reports of the South Pacific Commission as they form part of its northern region. They will therefore also be considered in this context in a companion paper.

Nevertheless, some earlier data supplied to the South Pacific Commission of the Trust Territory of the Pacific Islands confirm the absence of syphilis before 1972 (although very few cases have been reported since ${ }^{13}$ ) and also provide figures for gonorrhoea before 1971 with a breakdown according to Districts. Palau in the Caroline Islands was the district with the highest number of cases (table VII). In 1972 efforts to control gonorrhoea in that country were being intensified by such means as the use of screening by culture of high-risk groups. Because of the insular situation and relatively small number of cases it seemed possible not only to control, but to eradicate, gonorrhoea in the Trust Territory using available technology. Predictably the application of this programme resulted initially in an increase in the number of cases being diagnosed before the number began to decline.

Thanks are expressed to Dr G Causse of the World Health Organisation, Geneva; Dr T Kuberski of the
TABLE VII Number of cases of gonorrhoea in Trust Territory of Pacific Islands 12

\begin{tabular}{lcrrr}
\hline & & \multicolumn{3}{c}{ No of cases } \\
\cline { 3 - 5 } Territory & Population (1973) & 1961 & 1966 & 1971 \\
\hline Mariana Islands & $14333^{*}$ & $0^{*}$ & 25 & 24 \\
Caroline Islands & 12673 & 96 & 266 & 338 \\
$\quad$ Palau & 12 & 8 & 97 & 124 \\
$\quad$ Yap & 23252 & 86 & 146 & 72 \\
$\quad \begin{array}{l}\text { Ponape } \\
\text { Truk }\end{array}$ & 31609 & 50 & 50 & 8 \\
Marshall Islands & 25045 & 31 & 119 & 95 \\
Total & 115251 † & 271 & 703 & 661 \\
\hline
\end{tabular}

*Rota only

†Includes 469 persons not allocated to districts

South Pacific Commission, Noumea, New Caledonia; and Dr P J Wiesner, Centre for Disease Control, Atlanta, Georgia, USA for kindly making available the statistics on which this paper was based.

\section{References}

1. Zimmet P. Diabetes in Pacific populations-price for westernisation. Proceedings of the Sixth Asia and Oceania Congress of Endocrinology, Singapore, 1978;256-65.

2. Zimmet $\mathbf{P}$. Regional workshop on cholera and other epidemic diseases in the Pacific, Noumea, New Caledonia, 24-28 April 1978. Report of the South Pacific Commission 1978;62-3.

3. Center for Disease Control. VD Fact Sheet 1970. Washington DC: United States Public Health Service, 1971.

4. Center for Disease Control. STD Fact Sheet, 34th edition, Washington DC: United States Public Health Service, 1979.

5. Center for Disease Control. VD Fact Sheet 1976, 33rd edition. United States Public Health Service, 1977.

6. Kuberski T, Perry S, Ohye R, Wiebenga N. Non-gonococcal urethritis in Hawaii. Hawaii Med J 1977;36:103-8.

7. Kuberski T. Evaluation of the indirect haemagglutination technique for the study of Trichomonas vaginalis infections, particularly in men. Sex Transm Dis 1978;5:97-102.

8. World Health Organisation. World Health Stat Rep 1975; 28: 118,125 .

10. Willcox RR. Regional workshop on cholera and other epidemic diseases in the Pacific, Noumea, New Caledonia, 24-28 April. Report of the South Pacific Commission 1978:63-6.

11. Official Airline Guide. Hinsdale, Illinois: Reuben H Donnelley Corp, 1978.

12. South Pacific Commission. Annual Report of the South Pacific Epidemiological and Health Information Service for the Year 1978. Noumea, New Caledonia: South Pacific Commission, 1979.

13. Willcox RR. Venereal diseases in the islands of the South Pacific. Br $J$ Vener Dis (in press). 